NOTJCE

"Thls report was prepared as an account of work sponsored by the United States Government. Neither the United States nor the United States Energy Research \& Development Administration, not any of their employees, nor any of their contractors, subrontractors, or their emplayees, makes any warranty, express or implied, or assumes any legal liabillyty or responsibility for the accuracy. completeriess or usefutness of any intormation, apparatus, product or process disclosed, or represents that its use would not infringe privately-owned rights."

Printed in the United States of America

Available from

National Technical Information Service

U.S. Department of Commerce 5285 Port Royal Road

Springfield, Virginia 22151

Price: Printed Copy \$ $\$$; Microfiche $\$ 2.25$

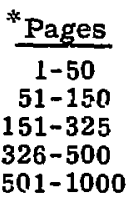

NTIS

Selling Price

$\$ 4.00$

$\$ 5.45$

$\$ 7.60$

$\$ 10.60$

$\$ 13.60$ 


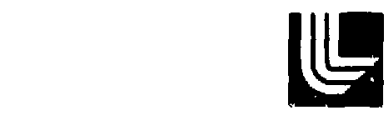

LAWRENCE LNERMOAE LAEORATOAY

Univerity or Cemomis Livemonacavon 94550

\section{UCRLL-51981 \\ TACTICAL NUCLEAR STUDIES: A MORE COMPREHENSIVE APPROACH \\ D. Blumenthal \\ C. Kooshian \\ G. Reinhardt \\ G. Sczehle}

MS. Date: December 18, 1975

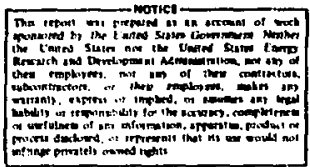

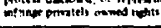


Contents

Abstract . . . . . . . . . . . . . . . . . . . . . 1

Intraduction . . . . . . . . . . . . . . . . . . . . . . 1

A thotce of scenartos . . . . . . . . . . . . . . . . . 1

A Checkllst . . . . . . . . . . . . . . . . . . . . 2

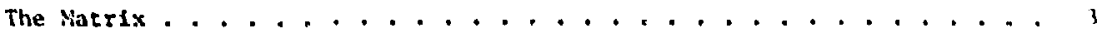

vtility . . . . . . . . . . . . . . . . . . . . . 6

Example . . . . . . . . . . . . . . . . . . . . . . 7

Sunnary . . . . . . . . . . . . . . . . . . . . 7

Acknowled knents . . . . . . . . . . . . . . . . . . . . 8

Appendix $\lambda$ : Typical Questions that Mtght ardse from Evaluation Charasterislies . . . . . . . . . . . . . . . . . . 9

-11i- 


\title{
TACTICAL NUCLEAR STUDIES: A MORE COMPREHENSIVE APPROACH
}

\begin{abstract}
Proposes a matrix scheme for dependent conclusions, ease of wainevaluating complex tactical nuclear systems. Advantages resulting from consideration of system characteristics in peace and crisis as well as war include avoldance of scenariotaining awareness of relationships between imediate concerns and the complex whole, and highlighting of areas or concerns that have been overlooked or neglected.
\end{abstract}

\section{Introduction}

Any malysis of tactical nuclear weapons is complicated by an Interrelated set of technical, operational, and political factors. Because of this most studies start with a number of simplifying assumptions designed to make the subject more tractable, either by treating lsolated porticns of the problem or by introducing $a$ specific scenarlo as a setting. Either approach leads to canclusions that of ten prove to be shortsighted, unduly scenario dependent, or otherwise wrong.
We suggest a conceptual framework that can alleviate such problems by enabling the analyst to more easily maintain his perspective; that is, to maintain an awareness of the relationship of his immediate concern to the complexities of the wiole. The approach lends itself to use as a platform for discussion and comparison both of weapon system concepts and actual hardware. It can further be used to Iaveal areas which have suffered from incomplete evaluation.

\section{A Choice of Scenarios}

All analyses that are scenario dependent rely on the analyst's zuess as to that spectific future may be most realistic or most helpful in evaluating a nuciear posture. We suggest that this is dangerous in 
that, without a basic philosophy to guide him, the analyst may choose an Inappropriate scenario that favors one particular tactical posture at the expenise of another when in fact an entirely different scenario may be of dominant importance.

In general, the military planner evaluates tactlca! nuclear systems for their war-fighting capability. In contrast the politiclan and the diplomat seem to think primar1ly of the deterrent value of tactical nuclear forces, assuming, perhaps implicitly, that the world will remain at peace. Thus tactical nuclear systems are typlcally evaluated in the light of extreme conditions, $1 . e$. efther peace or war. Thls can produce requirements or chsracteristics that are in conflict, inconsistent, or incompatible.

A thirc condition, one that has recelved little anaiysis and one that
In many cases may be of overriding importance, is the rondition midway between peace and war: crisis. Here we refer to the critical periods that accompany such events as the Six-Day War, the British-French intervention in Suez, the Soviet intervention Into Czechoslovak1a, the Cuban Misaile situation, or the GreekTurkish confrontation in Cypress. Proliferation of critical and highly sensitive issues affecting tactical nuclear weapons is likely to occur under this third condition. In order to reduce both restrictive scenarto dependence and embarassing inconsistencies in requirements or characteristics we argue that any military posture, any tactical nuclear system, must be evaluated in the light of all three conditions, peace, crisis, and war, not merely in a single detalled peace or war scenario.

\section{A Checklist}

We have suggested that these three conditions be used to shape thinking about sactical nuclear systems. WithIn each of these, one can then construct a checklist of important attributes haracterlzing the concepts or systems under study. In our experience this approach has been useful in maintaining balanced analysis.

We have been able to group these attributes into six major areas: (1) Military ef fectiveness and col-lateral damage, (2) Vulnerability, (3) Dual capab1lity, (4) Costs, (5) Safety, and (6) Communications, 
control and release, * These six neither exhaust the subject, nor are they mutually exclusive, but they do rorm a logical set for discussion. Much of the confusion that sometimes surrounds the issue of nuclear weapons comes from an attempt to deal with these factors singly as if they coul I be isolated from each other. But the real problems inherent in evaluating our nuclear posture are precisely due to the mutual interaction of these factors, and also to the necessity for the posture to be acceptable across the entire scenario spectrum from peace through crisis to war.
Without arguing for a particular priority of importance for these attributes, we feel that all weapons systems must achieve desired military effects without causing unacceptable levels of collateral damage; must be as survivable as possible within the constraints of force structure, use, and priority; should be dual capable at least for the forseeable future; must meet cost constraints in terms of dollars, special nuclear materials, and manpower; must be safe; and must be controllable and releaseable in timely fashion.

\section{The Matrix}

This leads us to our basic concept: that analysis of tactical nuclear systems can be guided by a matrix of attributes vs conditions. In one dimension are the conditions of peace, crisis, and war. In the other are the attributes mentioned above. Thus the basic matrix is only 3 by 6 in size (Fig. 1). A system or cuncept can then be evaluazed against each

\footnotetext{
`see W. S. Bennett, R. P. Gard, and G. C. Relnhardt, Tactical Nucisar Weapons: Objectives and Constraints, Los Alamos Scientific Laboratory, Albuquerque, New Mexico, Rept. LA5712-MS (1974).
}

of the matrix elements to determine areas of strength and weakness. Similarly, different systems can be compared for redundancy, complementarity, etc.

For each attrioute, one can define a set of evaluation characteristics. From these, a set of questions $c$ in be constructed that relates to the advantages and disadvartages of any given system when evaluated against the pertinent condition and attribute. Some of these questlons may be common to all three conditions; others specific to one or two. Table 1 illustrates a nonexhaustive set of 


\begin{tabular}{|l|l|l|l|}
\hline \multicolumn{3}{|c|}{ Toctical nuclear system evcluation matrix } \\
\cline { 2 - 4 } & \multicolumn{1}{|c|}{ Peace } & Crisis & Wor \\
\hline $\begin{array}{l}\text { Military effectivenes. } \\
\text { cuilateral damage }\end{array}$ & & & \\
\hline $\begin{array}{l}\text { Vulrerability/ } \\
\text { survivability }\end{array}$ & & & \\
\hline $\begin{array}{l}\text { Dual capability } \\
\text { Costs }\end{array}$ & & & \\
\hline $\begin{array}{l}\text { Safety } \\
\text { Communications, control } \\
\text { and release }\end{array}$ & & & \\
\hline
\end{tabular}

Fig. 1. The basic matrix.

evaluation characteristics and Appendix A a resulting set of questions. *

\footnotetext{
* In the hands of the skilled and experienced tactical analyst, the conceptual matrix may well be enough to focus attention on issues of critical importance. Indeed, different sets of questions may be pertinent to different studies.
}

The matrix is used to generate questions in the mind of the analyst, permitting him to move from one detailed consideration to another. Its magnitude, however, is such that the interplay of pertinent scenarios and attributes can be assessed at the beginning and at the end of the detailed analysis. The forest is seen as well as the trees. 
Tahbe 1. Typical evaluation characteristics for a given tactical nuclear system.

1. Military effectiveness/

collateral damage

1.1 Response tinn

1.2 Ascuracy

1. 3 Kange

1.4 Yield flexibllity

1.5 Rate of fire

1.6 A11 weather

1.7 Avallabllity

$1.8 \mathrm{klll}$ mechaniem

1.9 Collateral damage mechanism

1. 10 System rellabilicy

1.11 Target app ${ }^{+1}$ cability

1.12 Mobility

1.13 Combat readiness

1.14 System usable in training

1.15 Complexity of skills required

1.16 Tests and inspections

1.17 Target acquistion limitation

1.18 Tension aggravation in alert

1.19 Overall credibility as deterrent

2. Vulnerability/survivability

2.1 Preemptive strike

2.2 Nonnuclear attack

2.3 Tactical actions

2.4 Paramilitary action

2.5 Transportation (accident)

2.6 Proliferation (redundancy)

2.7 Signature (EW, IR, photographic)

2.8 Mobility

2.9 Proximity to friendly units

3. Dual capability

3.1 Conventional utility

3.2 Nuclear capability add on costs

3.3 Transition flexibility (time)

3.4 Deterrence value

3.5 Tactical flexibility

3.6 Tension aggravation (visibility) 


\section{Costs}

4.1 EREA dollars

4.2 DOD dollars

4.3 Personnel

4.4 'Critical materlals

4.5 Time to replace in war

4.6. Political costs

4.7 Allied constraints

4.8 Training

5. Safery

5.1 Nuclea:

5.2 Command disable

5.3 Storage

5.4 Transportation

5.5 Repair and inspection

6. Communications, control and release

6.1 RIsk of unautitorized use

6.2 Time to release

6.3 Time to secure

6.4 Seiective yield release

6.5 Countermeasure risk

6.6 Flexibility to allied force

6.7 Rt.sk with allied force

6.8 Mobility vs communication

\section{Utility}

We suggest that this concept can be particularly helpful to planners of tactical force structures 'y highlighting those areas that have boen neglacted in previous studies. For example, the subject of military effectiveness in war has been analyzed extensively, but the subject of dual capability has been generally neglected.
As we have polnted out, the matrix approach may also be used to assist studies in a number of ways. For example, a new Idea or concept may be analyzed to see in which areas $1 t$ offers improvement over the existing posture and to understand more completely areas where present capab1jities could possibly be degraded. Alternatively, systems or hardware 
can be compared in varlous ways.

The comparisons can be specific, for example an examination of alternatives for realizing a particuiar concept; or they can be of a broader nature herein characteristics of generic weapon types ar. compared.

The vircue of this approach is conceptual completeness, a franework permitring serious and orderly study of compiex issues and questions. We make no clatim for reductlors in the time and effort expended in studies and analyser. We do claim that through 1 ts use the analyst will be challenged to understand and cope wth $a 11$ of the issues at hand. In our experience this concept has poincedly identifled our weaknesses and biases.

\section{Example}

The usd of this cuncept in the analysis of a tactioal system is quite straightforward. The result is nectssarily lengthy if it is to be complete, making it impractical to include an example in this brief paper. An example is avallable, however, in a prorotype study published by R\&D Associates. " This work, describing in exemplary detall four nuclear weapon system, is intended to provide a basis for assessing NATO nuclear force structure. It 1llustrates Iow cereful application of the approach described herefn can produce comprehensive analysis as well as a useful reference.

\section{Summary}

The conceptual matrix of conditions and attributes which we have defined can aid in the planning and evalud-

${ }^{\star}$ G. I. Tay lor, J. W. Maloney, V. S. Dudley, J. J. Esser, B. B. Dillaway, and D. E. Willis, Nuclear Weapons System Manual: Evaluation of Selected Characteristics in the Contexts of Peace, Crisis, and War, R\&D Associates, Marina del Rey, California, Rept. LRL-5S-15602 (1975) (title $U$, refort SRD). tion of tactical nuclear systems. The matrix is a guide to organizing analyses; its use should help the analyst avoid the pitfalls inherent in scenario-based studies, and help guard against the omission of critical issues.

We believe the use of this structure has value in wach of three phases of study development. The first is 
In scoping a new study effort by identifying those subelementa that have first-order importance. The second is in Identifying interrela- tionshifs of subelements uring the conduct of the study, and the third in reviewing the study for completeness and relevance.

\section{Acknowledgments}

We have been encouraged in this work by Commander James Martin of ATSD(AE). Helpful comments on the paper have also been recelved from

R. Gard of this Laboratory and from

G. Taylor and $J$. Maloney of $R \& D$ Associates. 


\section{Appendix A}

TYPICAL QUESTIONS THAT MIGHT ARISE FROM EVALUATION CHARACTERISTICS

\begin{tabular}{|c|c|c|c|}
\hline & feace & trisis & Har \\
\hline $\begin{array}{l}\text { Deary } \\
\text { affoctiviness/ } \\
\text { col]ateral } \\
\text { datange }\end{array}$ & 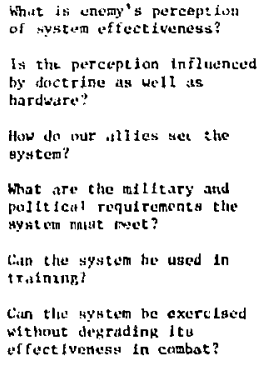 & 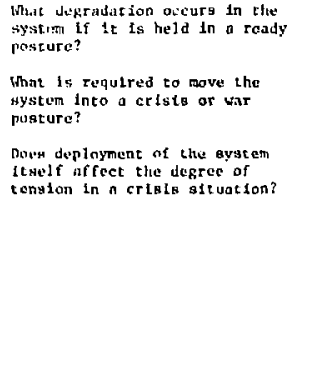 & 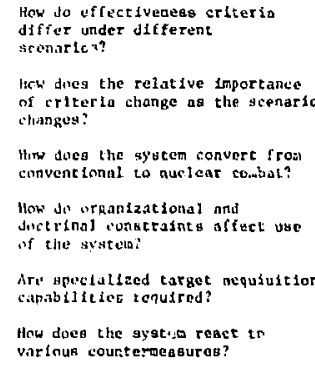 \\
\hline $\begin{array}{l}\text { vulnexalifillyl } \\
\text { survivability }\end{array}$ & 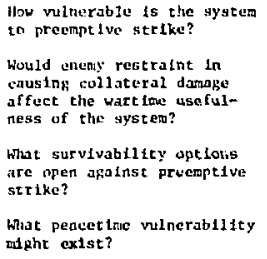 & 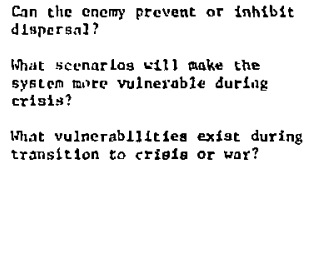 & 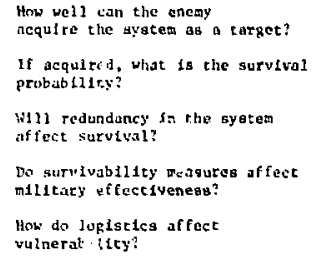 \\
\hline $\begin{array}{l}\text { Dual } \\
\text { capabiltty }\end{array}$ & 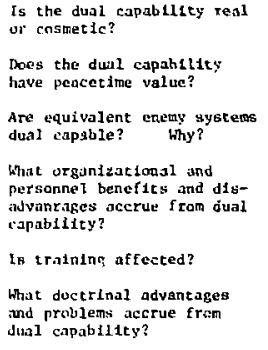 & $\begin{array}{l}\text { How daes dual capability affect } \\
\text { the transition to erisis and } \\
\text { war? }\end{array}$ & 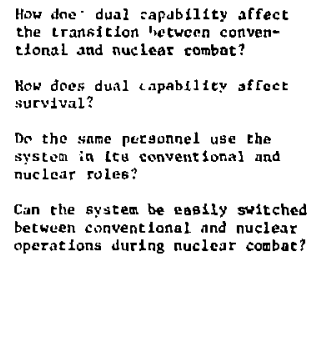 \\
\hline Linets & 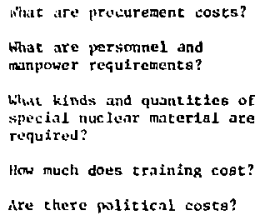 & 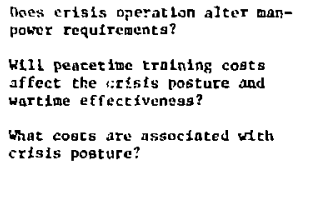 & 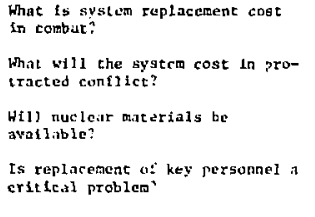 \\
\hline
\end{tabular}


Appendix A (continued)

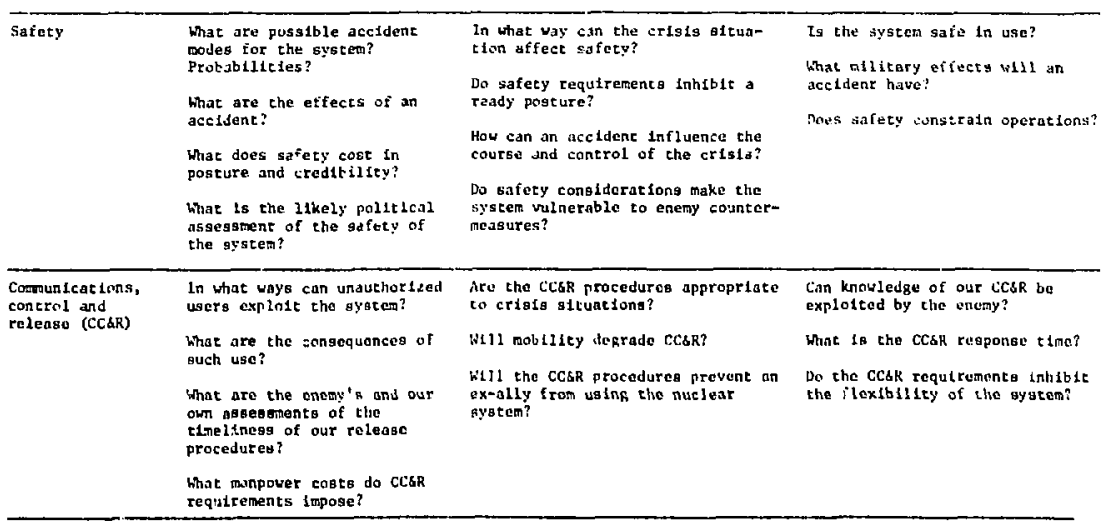

